\title{
A new isoetalean microsporophyll from the latest Albian of northeastern Spain: Diversity in the development and dispersal strategies of microspores
}

Uxue Villanueva-Amadoz, Luis Miguel Sender, José Bienvenido Diez, José Javier Ferrer, and Denise Pons

Acta Palaeontologica Polonica 59 (2), 2014: 479-490 doi: http://dx.doi.org/10.4202/app.2012.0010

In this paper well-preserved isoetalean microsporophyll, containing in situ microspores, is described from the uppermost part of the Utrillas Formation (latest Albian) in Teruel Province, northeastern Spain. Similar but dispersed microspores were described previously as Peromonolites. Fossil plant impressions and compressions including the sporophyll lamina and microsporangium are referred to the fossil genus Isoetites. Although Isoetes-like megafossil remains, often with in situ or associated megaspores, are known from quite a few Cretaceous sites, and dispersed microspores are known, the presence of intact microsporangia is rare. Herein we suggest that microsporangia may have dispersed in masses, possibly representing a new unknown strategy in microspore dispersal in this group of plants.

Key words: Lycophyta, Isoetales, Isoetites, Peromonolites, microsporophyll, Albian, Spain.

Uxue Villanueva-Amadoz [uxuevillanueva@yahoo.es], Department of

Paleontology, Geology Institute, Universidad Nacional Autónoma de México

(UNAM), Ciudad Universitaria, Coyoacán 04510 México D.F., Mexico; Luis M.

Sender [lmsender@unizar.es] and José J. Ferrer [joferrer@unizar.es], Department of Earth Sciences, University of Zaragoza, C/ Pedro Cerbuna 12, 50009 Zaragoza, Spain;

José B. Diez [jbdiez@uvigo.es], Department of Marine Geosciences and Land Use Planning, University of Vigo, 36310 Vigo, Spain; Denise Pons [denise.pons@ @nv.jussieu.fr], University of Pierre et Marie Curie (Paris 6), UMR 7207 CNRS, Centre Recherche Paléobiodiversité et Paléoenvironnements (CR2P), MNHN, Case courrier 48, 57 rue Cuvier, 75231 Paris cedex 05, France. 
distribution, and reproduction in any medium, provided the original author and source are credited.

Fof Full text $(951.5 \mathrm{kB})$ 